\title{
Faktor keberhasilan usaha pada UMKM industri sandang dan kulit di Kecamatan Wirobrajan Kota Yogyakarta
}

\author{
Rani Eka Diansari \\ Rendy Rahmantio \\ Universitas PGRI Yogyakarta \\ ranieka@upy.ac.id
}

\begin{abstract}
This study aimed to test the effect of using accounting information and capital on the business success of Micro Small and Medium Enterprises (MSMEs) in the Wirobrajan District, Yogyakarta Regency. The Population in this research is the MSMEs in Yogyakarta Regency. Sample taken there were only registered with the Department of Trade Industry and Cooperatives on Yogyakarta Regency, MSMEs in the clothing and leather industry, operating for more than five years, take notes on business management, the respondents as many as 34. The sampling technique used purposive sampling. The data analysis technique used in this research includes the quality of data consists of the validity and reliability test-the hypothesis consisting of the multiple linear regression analysis. The result indicates that accounting information and capital have a significant impact on business success.
\end{abstract}

Keywords: MSMEs, accounting information; capital; business success

\section{Pendahuluan}

Pembangunan perekonomian di Indonesia umumnya berbasis pada ekonomi kerakyatan, hal ini dapat dilihat pada sektor Usaha Mikro, Kecil dan Menengah (UMKM) yang merupakan salah satu bentuk usaha yang banyak dijalani oleh pengusaha di Indonesia. Sektor ini mempunyai peranan yang cukup besar dalam perekonomian nasional maupun daerah. Hal ini dikarenakan pengelolaan yang tidak sulit dan tidak membutuhkan biaya yang besar (Bee \& Christian, 2016). Usaha Mikro Kecil menjadi sumber mata pencaharian utama kegiatan informal. Usaha ini mempunyai karakteristik antara lain: berskala kecil, dimiliki oleh individu atau keluarga, menggunakan teknologi yang sederhana, bersifat padat tenaga kerja, pendidikan dan keahlian tenaga kerja rendah, dan tingkat upah yang relatif rendah. Keberadaan dan kelangsungan kegiatan informal di dalam perekonomian Indonesia merupakan realitas yang juga berperan dalam menyediakan peluang kerja bagi angkatan kerja. Kegiatan informal mampu menampung tenaga kerja dengan keahlian yang kurang. Sebagai dampak positif kegiatan informal adalah berkurangnya pengangguran (BPS, 2016).

UMKM memang terbukti peranannya di dalam perekonomian nasional, terutama dalam aspek peningkatan kesempatan kerja, pemerataan pendapatan, pembangunan ekonomi pedesaan, dan peningkatan ekspor non-migas. Namun disamping peran dan potensi yang dimiliki, UMKM menghadapi banyak permasalahan antara lain terbatasnya modal, rendahnya kualitas sumber daya manusia, serta kurangnya penguasaan ilmu pengetahuan dan teknologi (Sulistyo, 2010). Keberhasilan usaha merupakan keberhasilan bisnis yang dijalankan dalam mencapai tujuannya. Keberhasilan UMKM meliputi tujuh aspek antara lain peningkatan modal, peningkatan jumlah produksi, jumlah pelanggan, perluasan usaha, 
perluasan daerah pemasaran, perbaikan sarana fisik, dan peningkatan pendapatan usaha (Rini \& Laturette, 2016).

Keberhasilan usaha dipengaruhi oleh beberapa faktor namun faktor yang paling penting yang mempengaruhi keberhasilan usaha adalah informasi akuntansi. Informasi akuntansi dapat menjadi dasar yang andal bagi pengambilan keputusan-keputusan dalam pengelolaan usaha kecil antara lain keputusan pengembangan pasar, penetapan harga, dan lain-lain. Pengambilan keputusan yang tepat dapat menentukan keberhasilan dari sebuah usaha (Wibowo \& Kurniawati, 2015). Informasi akuntansi memiliki peran yang penting bagi pelaku bisnis dalam mencapai keberhasilan usahanya, namun praktek akuntansi keuangan UMKM di Indonesia masih rendah dan memiliki banyak kelemahan yang disebabkan oleh rendahnya pendidikan, kurangnya pemahaman terhadap Standar Akuntansi Keuangan (SAK) dari manajer atau pemilik, dan tidak adanya peraturan yang mewajibkan penyusunan laporan keuangan bagi UMKM (Wibowo \& Kurniawati, 2015). Banyaknya kendala yang dihadapi mengakibatkan banyak UMKM yang tidak bisa melanjutkan usahannya.

Faktor lain yang mempengaruhi keberhasilan usaha adalah modal usaha. Modal merupakan salah satu bagian yang penting saat mendirikan atau dalam menjalankan suatu usaha. Modal mengindikasikan kemampuan pelaku usaha dalam membiayai kegiatan operasional perusahaan (Rumerung, 2018). Modal usaha merupakan faktor usaha yang harus tersedia sebelum melakukan kegiatan produksi. Modal usaha merupakan kekayaan yang dimiliki perusahaan yang dapat menghasilkan keuntungann pada waktu yang akan datang. Besar kecilnya modal akan mempengaruhi perkembangan usaha dalam pencapaian pendapatan (Apriliani \& Widiyanto, 2018). Keberadaan modal memang sangat diperlukan dalam mendirikan dan menjalankan usaha, namun fenomena yang sering menjadi persoalan adalah bagaimana mengelola modal secara optimal sehingga bisnis yang dijalankan dapat dapat berhasil (Rumerung, 2018). Besar kecilnya modal menjadi masalah tersendiri bagi UMKM. Modal yang terlalu besar dari apa yang dibutuhkan akan menambah beban pembiayaan, terlebih apabila modal tersebut bukan modal sendiri. Sebaliknya jika modal terlalu sedikit akan menyulitkan jalannya usaha yang akan dilakukan. Pada usaha mikro dan usaha kecil sering kali belum ada pemisahan antara keuangan keluarga dengan keuangan usaha, sehingga masalah besarnya modal ini bisa menghambat keberhasilannya. Fenomena lain yang juga sering dijumpai pada UMKM yaitu tidak stabilnya modal, ketika UMKM memiliki permintaan akan produk banyak maka jumlah modal yang digunakan ikut meningkat sebaliknya ketika permintaan akan produk UMKM menurun maka modal yang akan digunakanpun ikut menurun (Indriyatni, 2013).

Berdasarkan permasalahan-permasalahan tersebut diduga keberhasilan UMKM dipengaruhi oleh penggunaan informasi akuntansi dan modal usaha. Peneliti termotivasi melakukan penelitian ini karena UMKM memiliki peran penting sebagai pemain utama dalam kegiatan ekonomi di berbagai sektor, penyedia lapangan kerja terbesar, pencipta pasar baru dan inovasi. Selain itu, fenomena yang terjadi penerapan akuntansi pada UMKM masih rendah dan masih menghadapi kendala dalam hal akses modal dan pendanaan. Motivasi kedua adalah hasil penelitian terdahulunya yang berkaitan dengan UMKM memiliki hasil yang berbeda-beda. Penelitian yang dilakukan Hanum (2013) menunjukan bahwa variabel 
informasi akuntansi tidak mempunyai pengaruh terhadap keberhasilan usaha. Sedangkan hasl penelitian yang dilakukan Wibowo \& Kurniawati (2015) menunjukan terdapat pengaruh positif antara karakteritik penggunaan informasi akuntansi terhadap keberhasilan usaha. Hasil penelitian yang dilakukan Apriliani \& Widiyanto (2018) menunjukan bahwa terdapat pengaruh signifikan antara modal dan keberhasilan usaha. Sedangkan penelitian yang dilakukan Ratnasari (2017) menunjukkan variabel modal usaha tidak berpengaruh signifikan terhadap keberhasilan usaha.

\section{Kajian Teori Dan Pengembangan Hipotesis}

\subsection{Usaha Mikro Kecil dan Menengah (UMKM)}

Menurut UU No. 20 tahun 2008 tentang UMKM, Usaha Mikro adalah usaha produktif milik orang perorangan dan/atau badan usaha perorangan yang memenuhi kriteria Usaha Mikro sebagaimana diatur dalam UU. Usaha Kecil adalah usaha ekonomis produktif yang berdiri sendiri, yang dilakukan oleh orang perorangan atau badan usaha yang bukan merupakan anak perusahaan atau bukan cabang perusahaan yang dimiliki, dikuasai, atau menjadi bagian baik langsung maupun tidak langsung dari Usaha Menengah atau Usaha Besar yang memenuhi kriteria Usaha Kecil sebagaimana dimaksud dalam UU.

Tabel 1. Kriteria UMKM menurut UU No. 20 tahun 2008

\begin{tabular}{cllc}
\hline \multirow{2}{*}{ No. } & & \multicolumn{2}{|c|}{ Kriteria } \\
\cline { 3 - 4 } & & Aset (Rp) & Omzet (Rp) \\
\hline 1. & Usaha Mikro & $\leq 50$ juta & $\leq 300$ juta \\
2. & Usaha Kecil & $>50$ Juta -500 Juta & $>300$ Juta $-2,5$ Miliar \\
3. & Usaha Menengah & $>500$ Juta -10 Miliar & $>2,5$ Miliar - 50 Miliar \\
\hline
\end{tabular}

\subsection{Keberhasilan Usaha}

Keberhasilan usaha bisa diidentifikasi dengan besarnya skala usaha yang ditandai dengan menningkatnya volume produksi dan mampu mengolah bahan baku yang lebih banyak. Kriteria yang lain didasarkan pada jumlah karyawan (karyawan yang bekerja banyak, pergantian karyawan rendah, masa kerja karyawan dan tingkat pendidikan karyawan) dan tingkat omzet penjualan (Wibowo \& Kurniawati, 2015).

Informasi akuntansi biasanya digunakan sebagai dasar untuk pengambilan keputusan dalam bisnis. PIA sangat bermanfaat dalam merencanakan, mengelola dan mengevaluasi usaha. PIA dapat membantu pengelolaan kegiatan usaha menjadi lebih baik, sehingga mampu menunjang KU (Wibowo \& Kurniawati, 2015). Penelitian Bee (2016) menyatakan bahwa adanya pengaruh variabel PIA terhadap KU secara positif. PIA dapat digunakan manajemen perusahaan dalam melakukan perencanaan serta membantu dalam pengambilan keputusan pengelolaan bisnis. Selain itu, PIA juga diperlukan ketika para pengusaha ingin mengakses bantuan dari pemerintah atau tambahan modal dari lembaga keuangan. Berdasarkan paparan diatas maka didapat hipotesis yaitu:

$H_{1}$ : Penggunaan Informasi Akuntansi (PIA) berpengaruh terhadap keberhasilan usaha. 


\subsection{Modal Usaha}

Modal usaha menjadi salah satu faktor penting dalam kegiatan berwirausaha, sebuah usaha tidak dapat dilakukan tanpa adanya modal usaha. Besar kecilnya modal usaha mempengaruhi keberhasilan usaha karena ketersediaan modal usaha yang cukup akan menentukan kelancaran dan jalannya pengembangan usaha (Feriansyah et al., 2015). Modal usaha dapat diartikan sebagai dana yang dirgunakan untuk menjalankan usaha agar dapat tetap berlangsung. Modal dalam berwirausaha dapat dilihat dari berbagai segi yaitu modal untuk memulai sebuah usaha, modal untuk melakukan perluasan usaha dan modal untuk menjalankan kegiatan operasional setiap hari (Agustina, 2015). Penelitian terdahulu menjelaskan adanya pengaruh modal usaha terhadap keberhasilan usaha yang artinya apabila modal usaha mengalami kenaikan maka keberhasilan usaha juga akan mengalami kenaikan (Apriliani \& Widiyanto 2018; Safitri \& Setiaji 2018). Sesuai dengan penjelasan diatas maka didapatkan hipotesis berikut:

\section{$H_{2}$ : Modal usaha berpengaruh terhadap keberhasilan usaha.}

\section{Metode penelitian}

Populasi dalam penelitian ini adalah UMKM di Kecamatan Wirobrajan Kota Yogyakarta yang terdaftar di dalam Dinas Perindustrian Perdagangan dan Koperasi Kota Yogyakarta. Penentuan sampel menggunakan metode purposive sampling dengan kriteria UMKM industri sandang dan kulit, sudah beroprasi lebih dari 5 tahun, dan melakukan pencatatan atas pengelolaan usahanya.

Semua variabel diukur menggunakan pertanyaan pada kuesioner yaitu dengan skala 1 sampai 4. Variabel keberhasilan Usaha (KU) diukur dengan 7 indikator yang digunakan oleh (Wibowo \& Kurniawati, 2015) yaitu bertambahnya karyawan, meningkatnya omzet penjualan, meningkatnya modal, meningkatnya pendapatan, meningkatnya volume penjualan, meningkatnya jumlah produksi, dan meningkatnya jumlah alat produk. Variabel penggunaan informasi akuntansi diukur dengan 11 indikator yang digunakan oleh (Wibowo \& Kurniawati, 2015) yaitu penggunaan informasi akuntansi untuk proyeksi kebutuhan uang kas di masa yang akan datang, mengontrol biaya, mengukur produktivitas, meningkatkan produktivitas, memberikan dukungan terhadap proses produksi, penggunaan informasi operasi, penggunaan informasi akuntansi manajemen, penggunaan informasi akuntansi keuangan, penggunaan informasi statutory accounting, penggunaan informasi budgetary, dan penggunaan informasi additional accounting. Variabel modal usaha diukur dengan 4 indikator yang digunakan oleh (Apriliani \& Widiyanto, 2018) yaitu modal investasi awal, modal kerja, modal operasional, dan hambatan dalam mengakses modal.

\section{Hasil Penelitian dan Pembahasan}

Penelitian ini mengambil objek penelitian Usaha Mikro Kecil Menengah (UMKM) di Kecamatan Wirobrajan, Kota Yogyakarta, Daerah Istimewa Yogyakarta. Responden yang menjadi subjek dalam penelitian ini adalah pemilik Usaha Mikro Kecil Menengah (UMKM) industri sandang dan kulit dengan hasil data responden sebagai berikut: 
Tabel 2. Hasil data Responden

\begin{tabular}{lcc}
\hline Keterangan & Jumlah & Persentase \\
\hline Umur & 0 & $0 \%$ \\
$<30$ tahun & 10 & $29,4 \%$ \\
$31-40$ tahun & 18 & $52,9 \%$ \\
$41-50$ tahun & 6 & $17,7 \%$ \\
$>50$ tahun & & \\
\hline Jenis Kelamin & 26 & $76,5 \%$ \\
Laki-laki & 8 & $23,5 \%$ \\
Perempuan & & \\
Pendidikan & 4 & $11,8 \%$ \\
SD & 6 & $17,6 \%$ \\
SMP & 18 & $52,9 \%$ \\
SMA & 6 & $17,6 \%$ \\
Perguruan Tinggi & & \\
\hline Lama Usaha & 5 & $14,7 \%$ \\
$\leq 10$ tahun & 10 & $29,4 \%$ \\
$11-15$ tahun & 8 & $23,5 \%$ \\
$>20$ tahun & 11 & $32,4 \%$ \\
Staf & & \\
\hline
\end{tabular}

Hasil uji validitas variabel keberhasilan usaha (Tabel 3) menunjukkan bahwa setiap pertanyaan berada pada tingkat signifikansi dibawah 5\% $(0,05)$, maka dapat dinyatakan bahwa seluruh item pertanyaan pada variabel keberhasilan usaha adalah valid.

Tabel 3. Uji Validitas Keberhasilan Usaha

\begin{tabular}{cccc}
\hline Pertanyaan & $\begin{array}{c}\text { Pearson } \\
\text { Correlation }\end{array}$ & Sig. (2-tailed) & Keterangan \\
\hline Y1 & 0,511 & $0,002^{*}$ & Valid \\
Y2 & 0,702 & $0,000^{* *}$ & Valid \\
Y3 & 0,686 & $0,000^{* *}$ & Valid \\
Y4 & 0,751 & $0,000^{* *}$ & Valid \\
Y5 & 0,382 & $0,026^{*}$ & Valid \\
Y6 & 0,585 & $0,000^{* *}$ & Valid \\
Y7 & 0,663 & $0,000^{* *}$ & Valid \\
Y8 & 0,638 & $0,000^{* *}$ & Valid \\
Y9 & 0,543 & $0,001^{*}$ & Valid \\
Y10 & 0,721 & $0,000^{* *}$ & Valid \\
\hline
\end{tabular}

Keterangan: ** Sig $<1 \% ; * \operatorname{Sig}<5 \%$

Pengujian reliabilitas digunakan untuk mengetahui kuesioner apabila digunakan secara berulang kali dengan responden yang sama dan mendapatkan hasil yang konsisten dari waktu ke waktu. Variabel yang reliabel jika mempunyai nilai cronbach's alpha $>0,50$ (Sugiyono, 2016). Hasil uji reliabilitas penelitian ini membuktikan seluruh variabel yang digunakan terbukti reliabel, dapat dilihat pada tabel 4. Pengujian hipotesis menggunakan regresi linier berganda untuk membuktikan pengaruh variabel independen terhadap variabel dependen (Tabel 5). 
Tabel 4. Hasil Uji Reliabilitas

\begin{tabular}{lcc}
\hline Variabel & Cronbach's Alpha & Keterangan \\
\hline Penggunaan informasi akuntansi & 0,912 & Reliabel \\
Modal Usaha & 0,930 & Reliabel \\
KeberhasilanUsaha & 0,809 & Reliabel \\
\hline
\end{tabular}

Tabel 5. Hasil Uji Hipotesis

\begin{tabular}{lcccc}
\hline & B & t & Sig. & Ket \\
\hline Penggunaan informasi akuntansi & 0,176 & 2,726 & $0,010^{*}$ & $\mathrm{H}_{1}$ : diterima \\
Modal Usaha & 0,093 & 2,296 & $0,029 *$ & $\mathrm{H}_{2}$ : diterima \\
\hline F Hitung $=6,653$ & & & $0,004^{*}$ & \\
Adj. R Square $=0,255$ & & & & \\
\hline Keterangan: $*$ Sig $<5 \%$ & & & &
\end{tabular}

Hasil pengujian hipotesis menunjukkan pengaruh antara variabel penggunaan informasi akuntansi terhadap keberhasilan usaha yang dibuktikan dengan nilai t sebesar 2,726 dan signifikansi 0,010 $(<0,05)$, sehingga $\mathbf{H 1}$ diterima. Variabel modal usaha menunjukkan hasil berpengaruh terhadap keberhasilan usaha karena memiliki nilai $t$ sebesar 2,296 dan signifikansi 0,029 $(<0,05)$, maka $\mathbf{H 2}$ diterima.

Hasil penelitian ini mendukung penelitian yang dilakukan oleh Wibowo dan Kurniawati (2015) yang membuktikan bahwa pengunaan informasi akuntansi (PIA) berpengaruh terhadap keberhasilan usaha. PIA dapat digunakan oleh manajer atau pemilik perusahaan untuk membantu pekerjaan, misalnya untuk membantu melakukan perencanaan, mengambil keputusan bisnis, dan membantu dalam pengelolaan usaha. Informasi akuntansi biasanya juga diperlukan para pengsuaha hendak mengakses bantuan dari pemerintah atau modal tambahan dari lembaga keuangan.

Hasil penelitian ini mendukung penelitian, Purwanti (2012), Indriyatni (2013), Feriansyah (2015), Apriliani (2018) dan Safitri (2018) yang membuktikan bahwa modal usaha berpengaruh terhadap keberhasilan usaha. Menurut Andreas (2011), usaha kecil biasanya kelemahan yaitu kekurangan dana untuk memenuhi beban usaha, ditambah lagi belum ada pemisahan keuangan usaha dan keuangan rumah tangga. Modal usaha mempuyai peranan yang penting dalam menentukan keberhasilan usaha karena ketersedian modal usaha yang cukup akan mempengaruhi kelancaran usaha dan pengembangan usaha (Feriansyah, 2015).

\section{Kesimpulan, Keterbatasan dan Saran}

Berdasarkan hasil pengujian dan pembahasan yang telah diuraikan, dapat disimpulkan bahwa variabel penggunaan informasi akuntansi dan modal usaha berpengaruh terhadap keberhasilan usaha baik secara parsial maupun simultan. Implikasi dari penelitian ini khususnya bagi UMKM untuk dapat meningkatkan penggunaan informasi akuntansi dan mengoptimalkan modal usaha agar pengelolaan usaha lebih terkendali sehingga dapat meningkatkan keberhasilan usaha. 
Penelitian selanjutnya disarahkan agar dapat memperbanyak dan menggunakan variabel lain diantaranya kebijakan pemerintah, sumber daya manusia dilihat dari tingkat pendidikannya, kondisi perekonomian secara makro karena variabel independen dalam penelitian ini diketahui hanya mempunyai pengaruh sebesar $37,1 \%$ terhadap variabel dependen, dan sisanya dipengaruhi variabel lain sebesar $62 \%$. Bagi penelitian selanjutnya diharapkan untuk memperluas objek penelitian karena dengan memperluas objek penelitian data yang dapat diolah semakin banyak dan semakin menunjukkan tingkat keakuratan data terhadap kondisi sesungguhnya terkait objek penelitian, karena objek penelitian ini hanya UMKM Kecamatan Wirobrajan, Yogyakarta sehingga belum mampu memberikan gambaran secara menyeluruh tentang kondisi UMKM di Indonesia.

\section{Daftar Pustaka}

Agustina, T. S. (2015). Kewirausahaan: Teori dan penerapan pada wirausaha dan UKM di Indonesia. Jakarta: Mitra Wacana Media.

Apriliani, M. F., \& Widiyanto. (2018). Pengaruh karakteristik wirausaha, modal usaha dan tenaga kerja terhadap keberhasilan UMKM Batik. Economic Education Analysis, 7 (2), 761-776.

Bee, A., \& Christian, G. (2016). Peran penggunaan informasi akuntansi dalam pengambilan keputusan untuk menunjang keberhasilan. Jurnal EBBANK.

BPS. (2016). Sensus Ekonomi 2016: Analisis Hasil Listing Potensi Ekonomi Bantul. Yogyakarta: Badan Pusat Statistik Kabupaten Bantul.

Disperindag. (2019). UMKM KOTA JOGJA. Retrieved from Disperindag website: umkm.jogjakota.go.id

Ediraras, D. T. (2010). Akuntansi dan kinerja UKM. Jurnal Ekonomi Bisnis, 15, 152-158.

Feriansyah, I., Manullang, R. R., \& Aslinda. (2015). Analisis pengaruh faktor modal usaha, tingkat pendidikan, lokasi usaha, dan lama usaha (Studi kasus pada binaan Dinas Perindustrian dan Perdagangan Kota Pangkalpinang). Jurnal Ilmiah Progresif Manajemen Bisnis (JIPMB), 4(2), 27-38.

Ghozali, I. (2018a). Aplikasi Analisi Multivariate. Semarang: Badan Penerbit - Undip.

Ghozali, I. (2018b). Aplikasi Analisis Multivariate dengan Program IBM SPSS 25. Semarang: Badan Penerbit Universitas Diponegoro.

Hanum, Z. (2013). Pengaruh persepsi pengusaha kecil atas informasi akuntansi keuangan terhadap keberhasilan perusahaan. Jurnal Riset Akuntansi dan Bisnis, 13(2), 219-250.

Hubies, M. (2009). Prospek Usaha Kecil dalam Wadah Inkubator Bisnis. Bogor: Ghalia Indonesia.

Indriyatni, L. (2013). analisis faktor-faktor yang berpengaruh terhadap keberhasilan usaha mikro dan kecil (Studi pada ssaha kecil di Semarang Barat). Jurnal Stie Semarang, 5(1), 54-70.

KBBI. (2019). Kamus Besar Bahasa Indonesia Online. Retrieved from https://kbbi.web.id/

Rahayu, M. S. (2014). analisis faktor ekonomi, tingkat pendidikan dan kemampuan berwirausaha terhadap keberhasilan usaha bagi masyarakat di Desa Begal Kecamatan Kedunggalar Kabupaten Ngawi. Jurnal Ilmiah STKIP PGRI Ngawi, 13(1), 72-81.

Rini, A. D., \& Laturette, K. (2016). Relevansi sikap berakuntansi pelaku UMKM muda dan penggunaan informasi akuntansi terhadap keberhasilan usaha. Jurnal Riset Akuntansi dan Keuangan, 12(2), 85-93. 
Rumerung, D. (2018). Analisis tingkat keberhasilan Usaha Kecil Mikro dan Menengah di Kabupaten Maluku Tengah. Jurnal SOSOQ, 5(2), 75-92.

Safitri, H., \& Setiaji, K. (2018). Pengaruh modal usaha dan karakteristik wirausaha terhadap perkembangan Usaha Mikrodan Kecil Di Desa Kedungleper Kecamatan Bangsri Kabupaten Jepara. Economic Education Analysis Journal, 7(2), 792-800.

Sugiyono. (2017). Metode Penelitian Kuantitatif, Kualitatif, dan R\&D. Bandung: CV. Alfabeta.

Suryana, Y., \& Bayu, K. (2012). Kewirausahaan: Pendekatan Karakteristik Wirausahawan Sukses Ed. 2. Kencana.

Tambunan, T. (2012). Usaha mikro kecil dan menengah di Indonesia: isu-isu penting. LP3ES.

Undang-Undang. (n.d.). Undang-Undang Republik Indonesia Nomor 20 Tahun 2008 tentang Usaha Mikro, Kecil, dan Menengah.

Wibowo, A., \& Kurniawati, E. P. (2015). Pengaruh penggunaan informasi akuntansi terhadap keberhasilan Usaha Kecil Menengah (Studi Pada Sentra Konveksi di Kecamatan Tingkir Kota Salatiga). Jurnal Ekonomi Dan Bisnis, XVIII, 107-126. 